\title{
Clinical anophthalmia and coloboma associated with systemic malformations: etiology and ophthalmologist-patient relationship
}

\author{
Anoftalmia clínica associada a coloboma e malformações \\ sistêmicas: etiologia e relação oftalmologista-paciente
}

Pedro Ventura', Rafael Bortoli Debarba², Bruna Zago ${ }^{3}$, Diego Davi Corso ${ }^{4}$, Elcio Luiz Bonamigo ${ }^{5}$

\begin{abstract}
This report refers to a two years and nine months patient, carrier of clinical anophthalmia in her right eye associated with posterior coloboma in her left eye and systemic malformations. The mother was vaccinated against rubella three months before conception and, at birth, the laboratory tests showed $267 \mathrm{IU} / \mathrm{mL}$ for rubella Ig G antibodies level and 3,5 IU/mL for cytomegalovirus, being IgM antibodies negative for both. The abnormalities found have characteristics of congenital rubella syndrome (CRS) and congenital cytomegalovirus infection. It can also constitute genetic alteration, derive from other etiologies or present themselves without explanation. The patient's psychological evaluation was within normal limits, being referred for vision rehabilitation. The mother manifested depressive symptoms, being shown to her specialized treatment. Further studies are needed to clarify the etiology of congenital eye malformations and the holistic cares to be valued during the relationship ophthalmologist-patient.
\end{abstract}

Keywords: Anophthalmos; Microphthalmos; Congenital abnormalities; Adaptation, Psychological; Case reports

\section{RESUMO}

O presente relato refere-se a uma paciente de 2 anos e 9 meses de idade, portadora de anoftalmia clínica à direita associada a coloboma posterior à esquerda e malformações sistêmicas. A mãe foi vacinada contra rubéola três meses antes da concepção e, ao nascimento, os exames laboratoriais mostraram título de anticorpos IgG de $267 \mathrm{UI} / \mathrm{mL}$ para rubéola e 3,5 UI/mL para citomegalovírus, sendo o IgM negativo para ambos. As anormalidades encontradas possuem características de síndrome da rubéola congênita (SRC) e infecção congênita por citomegalovírus. Também podem constituir alteração genética, decorrer de outras etiologias ou apresentarse sem explicação. A avaliação psicológica da paciente foi normal e a mesma encaminhada para reabilitação visual. A mãe manifestou sintomas depressivos e indicado tratamento especializado. Outros estudos serão necessários para esclarecer a etiologia das malformações oculares congênitas e os cuidados holísticos a serem valorizados durante a relação oftalmologista-paciente.

Descritores: Anoftalmia; Microftalmia; Anormalidades congênitas; Adaptação psicológica; Relatos de casos

\footnotetext{
${ }^{1}$ Fresh out of the Curso de Medicina da Universidade do Oeste do Estado de Santa Catarina (UNOESC) - Campus de Joaçaba (SC), Brazil;

${ }^{2}$ Fresh out of the Curso de Medicina da Universidade do Oeste do Estado de Santa Catarina (UNOESC) - Campus de Joaçaba (SC), Brazil;

${ }^{3}$ Academic of the Curso de Medicina da Universidade do Oeste do Estado de Santa Catarina (UNOESC) - Campus de Joaçaba (SC), Brazil;

${ }^{4}$ Doctor in Xanxerê (SC), Brazil.

${ }^{5}$ Doctor, Professor of Universidade do Oeste do Estado de Santa Catarina (UNOESC) - Campus de Joaçaba (SC), Brazil.
}

Study carried out at the University of the West of the State of Santa Catarina - UNOESC, campus Joaçaba (SC), Brazil.

The authors declare no conflicts of interests.

Received for publication 15/08/2012 - Accepted for publication 03/12/2012 


\section{INTRODUCTION}

A nophthalmia consists of a congenital or acquired malformation that is characterized by the absence of one or both eyes. True anophthalmia is a rare condition in which there is no development of the optical vesicle, and the histological research is negative. In practice, the concept of clinical anophthalmia is adopted, in which there is no clinical or radiological evidence of eyeball in the orbit ${ }^{(1)}$. Microphthalmos is the decrease of the total axial length of the eyeball due to the interruption of its development.

The present report refers to a patient with clinical anophthalmia or severe microphthalmos associated to posterior coloboma of the contralateral eye and systemic anomalies. The research project was approved by the Ethics Committee by Protocol No. 012/2011.

\section{CASe Report}

Female patient, white, 2 years and 9 months of age, resulting from the third normal pregnancy, 28-year father, 30-year mother, couple without inbreeding. She has two brothers, one from a previous relationship of the father and other from the current one, aged 14 and 8 years respectively.

The mother had adequate prenatal follow-up and denied hypertension, diabetes or gestational complications. She reported using hyoscine on first semester of pregnancy. She denied using alcohol, tobacco or drugs. Family history of congenital malformations was negative. She was vaccinated against rubella in $08 / 13 / 08$, third month prior to giving birth.

The cesarean delivery went well. She weighed 2,605g at birth, measured $44 \mathrm{~cm}$ in height and had an apgar score of 10-10. As abnormalities, anophthalmia (Figure 1), microphthalmos, syndactyly in one hand and oligodactyly in both feet (Figure 2) were found.

At birth she was tested negative for syphilis, toxoplasmosis, hepatitis B and HIV, but positive for the titles of IgG antibodies to rubella, amounting to $267 \mathrm{IU} / \mathrm{mL}$, and cytomegalovirus, amounting to $3.5 \mathrm{IU} / \mathrm{mL}$. The IgM was negative for both.

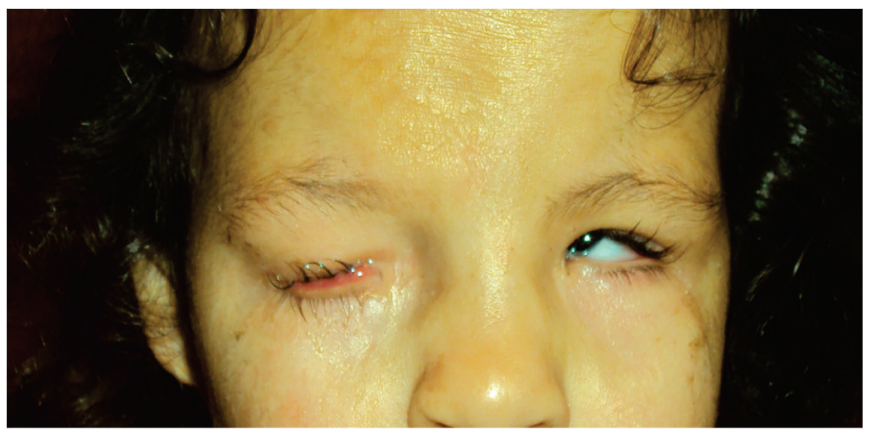

Figure 1. 21-month-old patient with clinical anophthalmia on the right.

The ocular echography showed bilateral absence of the eyeball on the right, with rudiments of tissues, and coloboma of the posterior wall on the left (Figure 3). Urinary tract ultrasound showed mild distortion of piel-calicial system of the left kidney, and the heart echodoppler showed persistence of inter-atrial communication.

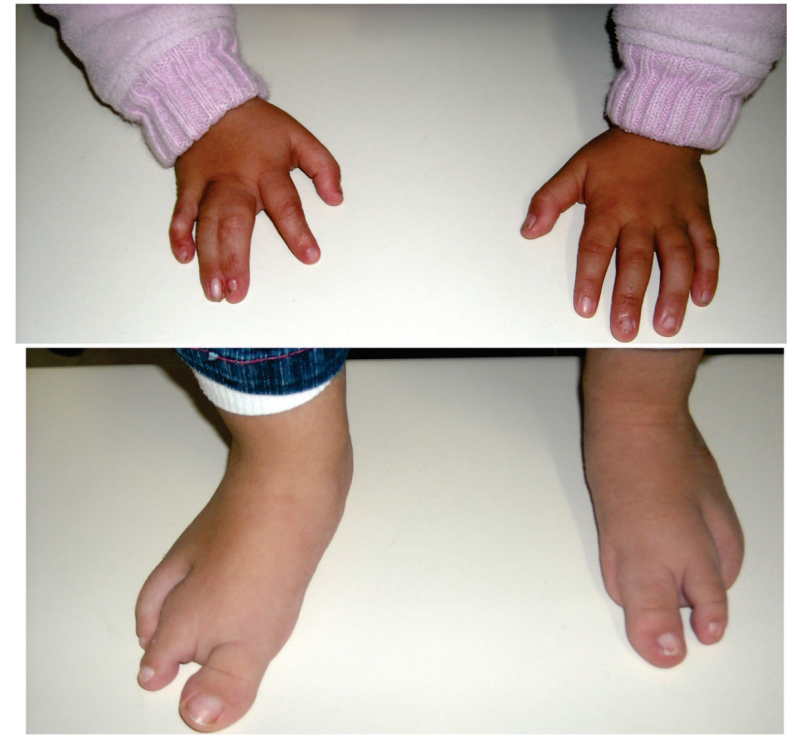

Figure 2. Syndactyly in the right hand and oligodactyly in both feet.

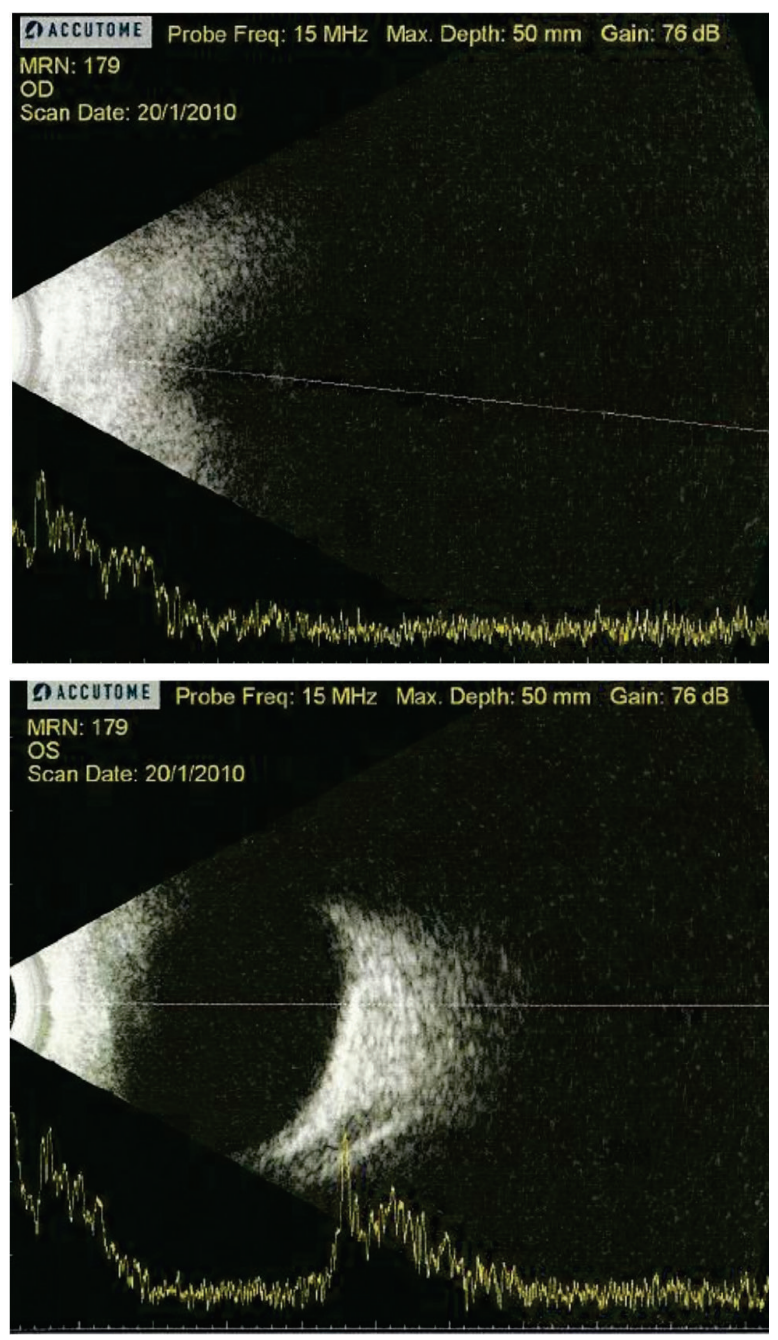

Figure 3. Ultrasound of orbits with rudiments of eyeball on the right and posterior coloboma on the left. 
The auditory evoked potential and the brain stem (ABR) revealed profound hearing loss on the right and no changes on the left. The cytogenetic study diagnosed normal female karyotype (Figure 4).

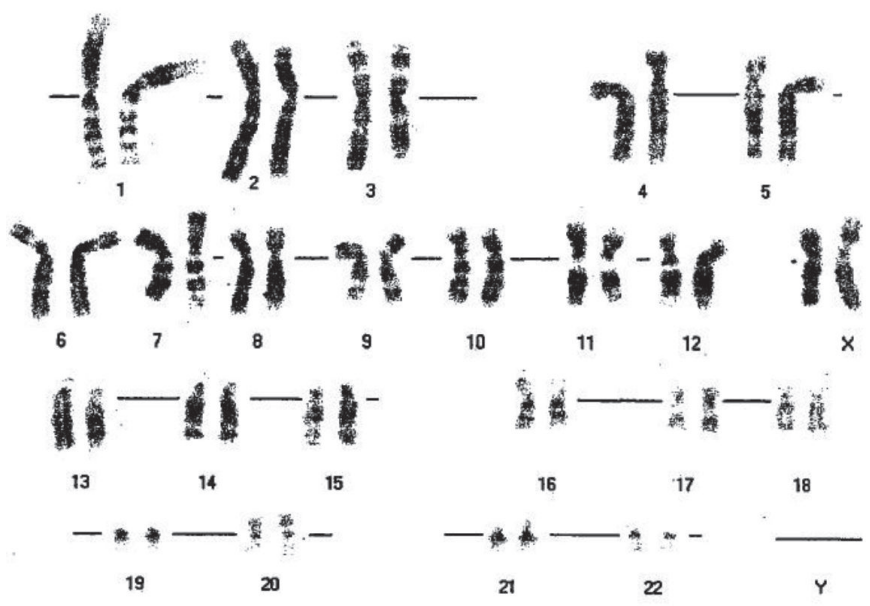

Figure 4. Karyotyping by G-banding with normal results.

The motor and psychological assessment was normal, and the visual acuity of the left eye seemed partially preserved, although without central fixation. Radiography showed skull with symmetrical configuration, cranial vault with normal thickness, density, structure and contour (Figure 5). The mother expressed depressive symptoms during the consultations, being referred to counseling follow-up.

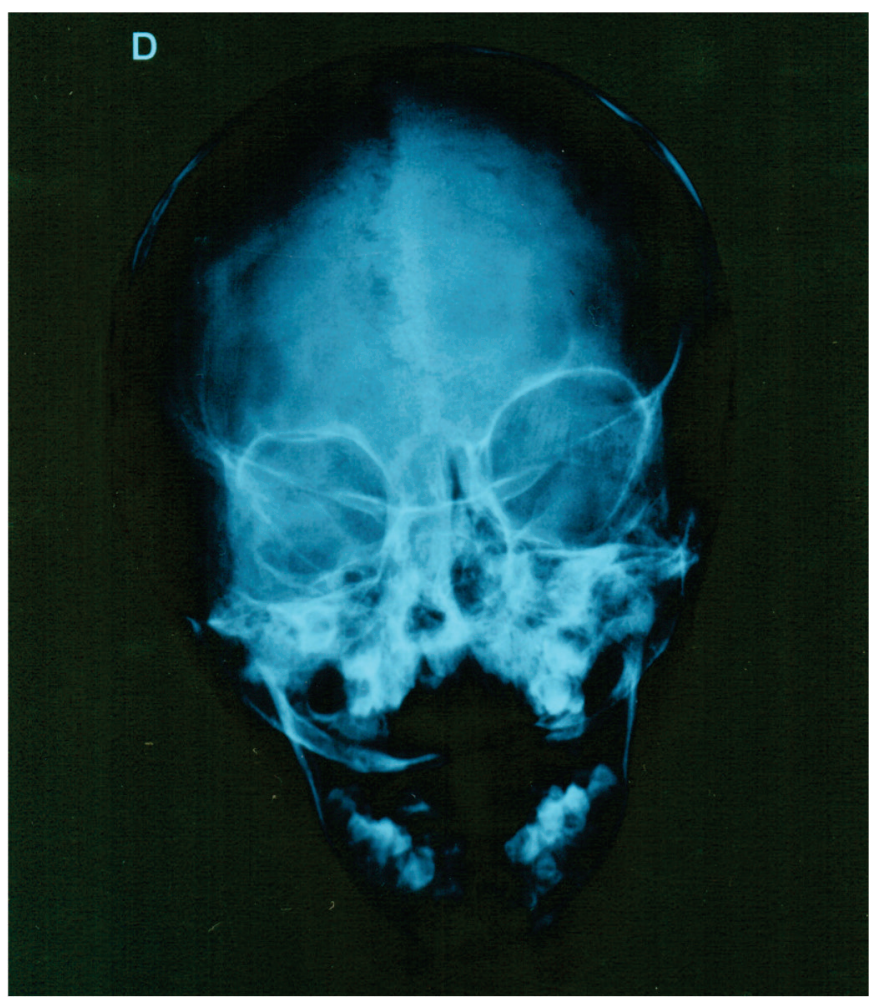

Figure 5. Skull radiography showing asymmetry of the orbital cavities without other abnormalities.

\section{DisCUSSÃO}

Anophthalmia and microphthalmos are rare ocular abnormalities which may compromise the psychosocial development of the individual affected. The patient care and their families by a multidisciplinary team contributes to the wellbeing and the social integration ${ }^{(2)}$. That is why the mother was referred to psychological treatment and the daughter to specialized treatment in visual rehabilitation center.

Anophthalmia and microphthalmos manifest alone or accompanied by systemic changes. The pathogenesis of the embryological development of anophthalmia is inaccurate. Microphthalmos may originate during the postnatal period for vitreous changes, decreased intraocular pressure or cyst development during the period of closure of the optical fissure. Among the factors that cause anophthalmia and microphthalmos are the pesticide Benomyl and the infections in the gestational period by: rubella, toxoplasmosis, chickenpox, cytomegalovirus, herpes zoster virus, parvovirus B19, influenza and coxsackie A9. Non-infectious causes happen by maternal deficiency of vitamin A, fever, hyperthermia, exposure to: $x$-ray, solvents, thalidomide, warfarin and alcohol, as well as by mutation of several genes ${ }^{(3)}$. When accompanied by syndactyly, anophthalmia and microphthalmos may be associated to the change of the genes BMP4, GDF6 and SMOC1; oligodactilia to gene SMOC1; the heart defects to SOX2; renal to genes SOX2, OTX2, SMOC1 and GDF6; coloboma to SOX2, OTX2, PAX6, RAX, BMP4, SMOC1 and GDF6; hearing problems to OTX2 and SOX2(4). Ischemic disorders were supposed as the etiological possibility of anophthalmia, which also occurs without explanation ${ }^{(5)}$

This patient presented high titers of $\mathrm{IgG}$ antibodies to rubella and cytomegalovirus at birth. But the mother had been vaccinated and laboratory confirmation for rubella in the third month of life did not occur. Later she was vaccinated, undermining the eventual diagnosis.

Congenital rubella is among the leading causes of infant blindness in Brazil, affecting between 27,000 to 32,000 children ${ }^{(6)}$. The availability of vaccine made it potentially avoidable, drastically reducing its occurrence. Ocular manifestations are: microphthalmos, anterior uveitis, retinopathy in "salt and pepper", cataract, keratopathy and refractive errors. The set of manifestations is called Congenital Rubella Syndrome (CRS), which affects the development of various organs, causing heart disease, blindness, deafness and multiple disabilities. The risk increases when the infection occurs during the first twelve weeks of pregnancy ${ }^{(7)}$.

A study that assessed 152 women vaccinated against rubella unaware of her pregnancy or who became pregnant within 30 days after vaccination was negative for $\operatorname{SRC}^{(8)}$. The Ministry of Health considered effective the vaccine safety when applied over thirty days of conception and with no association to $\mathrm{SRC}^{(9)}$. Events similar to our case is an association between vaccine and events unrelated to the vaccine, and can not be explained, they can be cytomegalovirus infection or be caused by other factors that trigger heart disease, craniofacial malformations or psychomotor disorders $^{(7)}$.

Congenital infection by cytomegalovirus can occur at any stage of pregnancy or during childbirth. The teratogenic potential is proportional to the early infection. The systemic manifestations in which there are cerebral calcifications, hepatosplenomegaly, chorioretinitis, thrombocytopenia, macular rash, hemolytic ane- 
mia and organ development impaired is called cytomegalic inclusion disease.

When there is anophthalmia or severe microphthalmia, the contralateral eye may be normal or carrier of abnormalities of the posterior segment, raising the need for future studies in an attempt to establish a relationship between th phenotype and the respective genotype ${ }^{(10)}$. Coloboma is a failure in the closing of the embryonic coroidal fissure during the 35 th to $41 \mathrm{st}$ week of pregnancy, and can affect the iris, ciliary body, choroid, sclera or retina ${ }^{(11)}$, as occurred in the present case and may be part of different syndromes.

This report draws attention to some etiologic possibilities concerning congenital ocular malformations and psychological care to be recovered during the ophthalmic patient assistance ${ }^{(12)}$. Noting the congenital malformation, the doctor's skill in communicating bad news can contribute to reducing the initial impact to the family. Even if the cause is not identified and the cure is unreachable, it will always be possible to provide benefits, not only by treating disease and assisting the patient, but also by guiding and comforting the family members who often find themselves under severe emotional trauma. So, through this holistic approach, the ophthalmologist can comply with the fundamental principle of the Code of Medical Ethics in acting humanistically in this relationship and to the best of their professional competence for the benefit of the patient ${ }^{(13)}$.

The national literature on the subject is scarce, and larger studies will be needed both to clarify the etiology of congenital ocular malformations and to guide the behavior of ophthalmologists to psychosocial events which took place in this ophthalmologist-patient relationship.

\section{ReFERÊNCIAS}

1. Dantas AM, Monteiro ML. Doenças da órbita. Rio de Janeiro: Cultura Médica; 2002.

2. Botelho NL, Volpini M, Moura EM. Aspectos psicológicos em usuários de prótese ocular. Arq Bras Oftalmol. 2002;66(5):63746. Autor: Botelho, Nara Lúcia Poli; Volpini, Marcos; Moura, Eurípedes da Mota.
3. Verma AS, FitzPatrick DR. Anophthalmia and microphthalmia. Orphanet J Rare Dis. [periódico na internet] 2007 [citado 2012 julho 10];2:47:[cerca de 8p]. Disponível em: http://www.biomed central.com/content/pdf/1750-1172-2-47.pdf

4. Slavotinek AM. Eye development genes and known syndromes. Mol Genet Metab. 2011;104(4):448-56.

5. Corso DD, Bonamigo EL, Corso MA, Rodrigues EB. Anoftalmia bilateral como defeito congênito isolado: uma abordagem etiológica e psicossocial. Rev Bras Oftalmol. 2011;70(4):243-7.

6. Taleb A, Ávila M, Moreira H. As condições de saúde ocular no Brasil - 2009. São Paulo: International Standard Book; 2009.

7. Brasil. Ministério da Saúde. Departamento de Vigilância Epidemiológica. Coordenação Geral do Programa Nacional de Imunizações. Informe Técnico $\mathrm{N}^{\circ}$ 2. Campanha nacional de vacinação contra a rubéola - 2008. Vacinação contra a rubéola: gestantes vacinadas inadvertidamente (GVI). $2^{\mathrm{a}}$ ed. [internet] 2008 [citado em 2012 maio 27]; [cerca de 5p]. Disponível em http://portal.saude.gov.br/portal/arquivos/pdf/informe rubeola2.pdf

8. Minussi L, Nascimento CR, Momino W, Sanchotene ML, Enéas LV, Bercini M, et al. Avaliação prospectiva de gestantes vacinadas contra a rubéola no sul do Brasil. Sci Med. 2007;17(3):119-23.

9. Brasil. Ministério da Saúde. Secretaria de Vigilância em Saúde. Rubéola: CID 10: B06. [internet] 2009 [citado em 2011 maio 28]; [cerca de 17p]. Disponível em: http://portal.saude.gov.br/portal/ arquivos/pdf/gve_7ed_web_atual_rubeola.pdf

10. Gerth C, Schittkowski M, Guthoff R. Ocular findings in the contralateral eye in patients with unilateral anophthalmia or nonfunctioning microphthalmia. J AAPOS. 2009;13(1):e16.

Parte inferior do formulário

11. Gujar SK, Gandhi D. Congenital malformations of the orbit. Neuroimaging Clin N Am. 2011;21(3):585-602, viii.

12. Leite M. Anoftalmia congênita. Apresentação de 5 casos. Rev Bras Oftalmol. 1970;29(3):75-9.

13. Conselho Federal de Medicina. Código de ética médica: Resolução CFM nº 1.931, de 17 de setembro de 2009 (versão de bolso). Brasília: Conselho Federal de Medicina; 2010.

\section{Corresponding author:}

Elcio Luiz Bonamigo

Rua Francisco Lindner, 31089600000 - Joaçaba, SC

Fax: 4935220717

E-mail: elcio.bonamigo@unoesc.edu.br 